\title{
Functional properties of developing rat Leydig cells after treatment with ethylene dimethanesulphonate (EDS)
}

\author{
J. T. M. Vreeburg, M. P. Ooms, F. F. G. Rommerts* and K. J. Teerds $†$
}

Departments of Endocrinology, Growth and Reproduction, and *Bochemistry, Erasmus University, Rotterdam, The Netherlands; and $\dagger$ Department of Cell Biology, Medical School, State University of Utrecht, The Netherlands

\begin{abstract}
Summary. The development of a new population of Leydig cells after specific elimination of existing Leydig cells in mature rats by ethylene dimethanesulphonate (EDS) was characterized by investigating the testicular activities of $5 \alpha$-reductase and non-specific esterase, the serum concentrations of $3 \alpha$-androstanediol and testosterone and the Leydig cell morphology. Plasma concentrations of both androgens were strongly reduced up to 15 days after administration of EDS. Thereafter, in contrast to the gradual and continuous increase of serum testosterone values, the changes in serum $3 \alpha$-androstanediol were transient, with the highest level on Day 35. The temporal pattern of testicular $5 a$-reductase activity was almost similar to that of serum $3 \alpha$-androstanediol. The testicular esterase activity increased gradually from Day 25 until Day 76. The temporal changes in steroid concentrations and enzyme activities after EDS administration indicate that the development of the Leydig cells in EDStreated rats occurs in a fashion similar to that in pubertal rats. However, the numerous lipid droplets and large nuclei in these Leydig cells indicate that these cells may also be classified as fetal cells.

It is concluded that, after treatment with EDS, fetal and pubertal characteristics are present in Leydig cells. It is, however, unknown whether both characteristics are present in one or in two distinct cell populations.
\end{abstract}

Keywords: ethylene dimethanesulphonate; Leydig cell; $5 \alpha$-reductase; esterase; $3 \alpha$-androstanediol; rat

\section{Introduction}

After a single dose of ethylene dimethanesulphonate (EDS) the Leydig cells in the testes of adult male rats are completely destroyed within $72 \mathrm{~h}$ (Kerr et al., 1985; Molenaar et al., 1986b; Bartlett et al., 1986; Jackson, N. C. et al., 1986; Jackson, A. E. et al., 1986; Morris et al., 1986; Teerds et al., 1986). During the first 2 weeks after this treatment there are no morphologically recognizable Leydig cells in the testis and the testosterone concentrations in the testis and in plasma are hardly detectable, despite high peripheral levels of gonadotrophins (Bu'Lock \& Jackson, 1975; Bartlett et al., 1986; Jackson, A. E. et al., 1986; Molenaar et al., 1986b). During the 3rd and 4th week, however, an increasing number of cells with morphological features of Leydig celis can be recognized in the testes and the testosterone concentrations rise (Kerr et al., 1985; Bartlett et al., 1986; Jackson, A. E. et al., 1986; Jackson, N. C. et al., 1986; Molenaar et al., 1986b; Morris et al., 1986). Subsequently, these new Leydig cells transform into normal adult Leydig cells. This process is completed within 10 weeks after treatment with EDS (Kerr et al., 1987).

It has been suggested that the development of Leydig cells after treatment with EDS might be different from the normal maturation during puberty, since the Leydig cells which repopulate the interstitium 3 weeks after EDS treatment have a number of morphological characteristics which are 
also found in the Leydig cells of fetal testes (Kerr et al., 1985, 1987; Bartlett et al., 1986; Jackson, A. E. et al., 1986).

The current information on the regeneration of Leydig cells after EDS treatment has been mainly obtained from morphological studies and this might be insufficient for a complete description of this process. More insight into the functional aspects of Leydig cell development can be obtained by measuring enzymic and steroidogenic activities which are known to alter during normal development. One of the features of Leydig cell maturation during development is a transient increase in steroid 5a-reductase activity (van der Molen et al., 1975; Rosness et al., 1977). This increase in testicular $5 \alpha$-reductase is accompanied by a rise in plasma $5 \alpha$-androstane- $3 \alpha, 17 \beta-$ diol (3$\alpha$-androstanediol) (Moger, 1977; Corpéchot et al., 1981). Another enzyme which can be used as a marker enzyme for a late stage of Leydig cell development is non-specific esterase (Meyer et al., 1974; Molenaar et al., 1986a). In this study we have measured testicular $5 \alpha$-reductase and esterase and serum $3 \alpha$-androstanediol as well as the occurrence of lipid droplets in EDS-treated rats and in 30-day old rats in order to characterize the functional properties of Leydig cell development after administration of EDS.

\section{Materials and Methods}

Treatment of animals. Locally bred $(\mathrm{R} \times \mathrm{U}) \mathrm{F}_{1}$ hybrid rats derived from two inbred Wistar rat strains were used. They were kept under standard animal house conditions (lights on 05:00-19:00 h) and had free access to food and drinking water. The changes in the testicular activities of $5 \alpha$-reductase and non-specific esterase, and the serum concentrations of testosterone and $3 \alpha$-androstanediol, were measured several days after treatment of mature rats with EDS. Thirty-five (35) 3-month-old rats were divided into 8 groups of 4-5 animals. Rats in Group 1 received a single injection of EDS $(75 \mathrm{mg} / \mathrm{kg}$ i.p. $)$ in dimethyl sulphoxide:water $(1: 3, \mathrm{v} / \mathrm{v})$. These rats were killed 76 days later. At intervals of 10-12 days the other groups of animals were injected. In this way all animals could be killed within 1 week at 7, 15, 25, 35, 46, 56, 66 and 76 days after injection of EDS. Trunk blood was collected and testes were removed. Five untreated rats served as controls.

The testicular $5 \alpha$-reductase values of EDS-treated rats 30 days after injection were also compared with those of untreated immature and mature rats: 5 adult male rats (4 months of age) received a single injection of EDS and 4 control rats were injected with vehicle only $(0 \cdot 2 \mathrm{ml} / 100 \mathrm{~g})$. At 30 days after treatment the animals were decapitated and their testes were removed and weighed. Simultaneously, 4 rats of 30 days of age were killed.

Measurement of enzyme activities. Testes were decapsulated and homogenized with a Teflon-glass homogenizer in Tris buffer (100 mg tissue $/ \mathrm{ml}$ buffer). The composition of the buffer was: $50 \mathrm{~mm}$-Tris, $5 \mathrm{~mm}-\mathrm{EDTA}, 50 \mathrm{~mm}-\mathrm{NaCl}$,

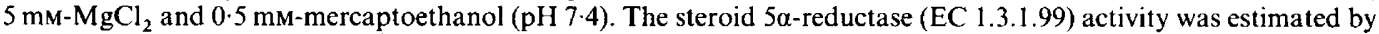
measuring the production of $\left[{ }^{3} \mathrm{H}\right] 5 \alpha$-dihydrotestosterone, $\left[{ }^{3} \mathrm{H}\right] 5 \alpha$-androstane- $3 \alpha, 17 \beta$-diol and $\left[{ }^{3} \mathrm{H}\right] 5 \alpha$-androstane$3 \beta, 17 \beta$-diol after incubation of $10 \mathrm{mg}$ tissue for $15 \mathrm{~min}$ at $37^{\circ} \mathrm{C}$ in $1 \mathrm{ml}$ of buffer containing $\left[{ }^{3} \mathrm{H}\right]$ testosterone $(0 \cdot 67 \mu \mathrm{M})$ and an NADPH-generating system. Incubations were terminated by adding $3 \mathrm{ml}$ cold ethylacetate containing $10 \mu \mathrm{g}$ $5 \alpha$-dihydrotestosterone, $10 \mu \mathrm{g} 3 \alpha$-androstanediol and $10 \mu \mathrm{g}$ testosterone. After collecting the ethyl acetate layer, the incubation medium was extracted twice more with ethyl acetate. Extracts were chromatographed on silica gel plates with chloroform-acetone $(85: 15 \mathrm{v} / \mathrm{v})$. Areas corresponding to $5 \alpha$-dihydrotestosterone, $5 \alpha$-androstane- $3 \alpha, 17 \beta$-diol, $5 \alpha$-androstane-3 $\beta, 17 \beta$-diol and testosterone were extracted and radioactivity was measured. Recrystallization to constant specific activity showed that the samples were at least $95 \%$ pure. For a comparison of $5 \alpha$-reductase activity in the testes from 30-day-old rats and from adult rats 30 days after EDS, a saturating concentration of $50 \mu \mathrm{M}$ testosterone was used. Non-specific esterase activity was measured as described by Rommerts et al. (1973).

Androgen determinations. The serum concentrations of testosterone and $3 \alpha$-androstanediol were estimated by radioimmunoassay after chromatography on thin-layer silica gel in a chloroform-acetone system ( $85: 15, \mathrm{v} / \mathrm{v})$ (Verjans et al., 1973; Meijs-Roelofs et al., 1985). The antisera against testosterone and androstanediol were as described by Verjans et al. (1973) and Rao et al. (1977). Steroids showing cross-reactivity with the antisera were eliminated by the thin-layer chromatography. The intra- and interassay variations were respectively $9 \%$ and $14 \%$ for testosterone and $13 \%$ and $15 \%$ for $3 \alpha$-androstanediol.

Morphology. For histological studies, testes of adult rats 30 days after EDS administration and testes of 30-dayold rats were perfused with $2 \%$ glutaraldehyde in $0.1 \mathrm{M}$-cacodylate buffer $(\mathrm{pH} 7 \cdot 2)$ and fixed for $18 \mathrm{~h}$ at $4^{\circ} \mathrm{C}$, followed by post-fixation in $0.1 \mathrm{M}$-cacodylate buffer containing $1 \% \mathrm{OsO}_{4}$ for $2 \mathrm{~h}$ at $4^{\circ} \mathrm{C}$. After dehydration the material was embedded in Epon and $0.5 \mu \mathrm{m}$ sections were made. These sections were stained with toluidine blue.

Statistical analysis. The results were subjected to a one-way analysis of variance, followed by Duncan's multiple range test, or to Student's $t$ test. 


\section{Results}

The serum concentrations of testosterone and $3 \alpha$-androstanediol were significantly $(P<0.05)$ reduced up to 15 days after injection of EDS (Fig. 1a). From Day 25 on, the serum values of both androgens increased. On Day 35 the concentrations of $3 \alpha$-androstanediol were significantly $(P<0.05)$ higher than on Day 0 whereas testosterone levels were not yet completely restored. After Day 35 serum $3 \alpha$-androstanediol values decreased to control levels, while the concentration of testosterone increased further. On Day 76 the concentration of testosterone was significantly $(P<0.05)$ higher than on Day 25.

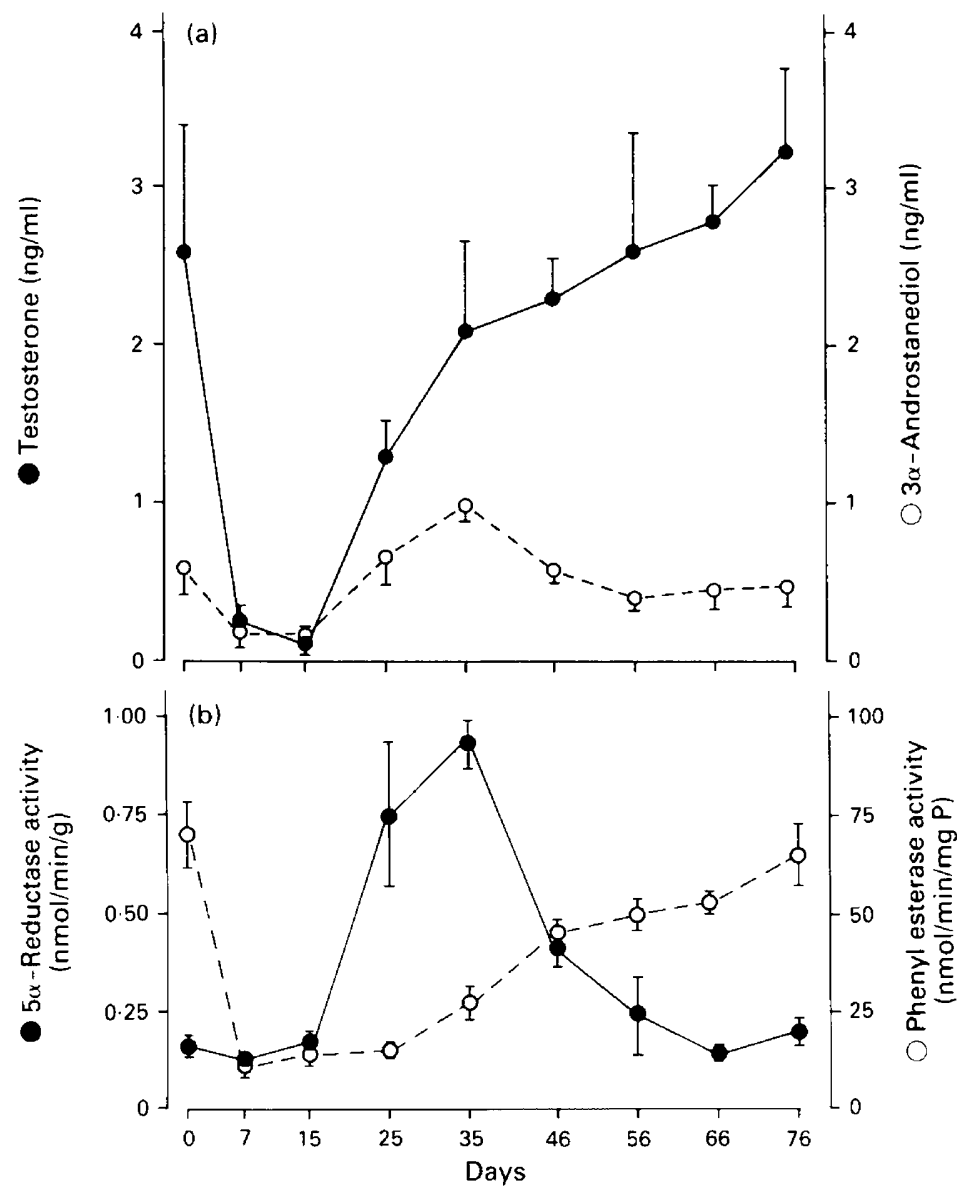

Fig. 1. Temporal changes in (a) the serum concentrations of testosterone and $3 \alpha$ androstanediol and (b) in the testicular activities of $5 \alpha$-reductase and phenyl esterase after a single injection of EDS into adult rats. Values are the mean \pm s.e.m. for 4-5 rats.

The testicular enzyme activities of $5 \alpha$-reductase on Days 7 and 15 after treatment with EDS were not significantly different from those measured on Day 0 (Fig. 1b). Thereafter the changes in $5 \alpha$-reductase paralleled the changes in the serum $3 \alpha$-androstanediol concentrations. The $5 \alpha$ reductase activity on Days 25 and 35 was significantly $(P<0 \cdot 01)$ higher than that on Days 0,7 and 
15. On Day 46 the $5 \alpha$-reductase activity was significantly $(P<0.01)$ lower than the enzyme level on Day 35 but still higher than on Day $0(P<0.05)$.

The pattern of testicular esterase activity after EDS was different from that of $5 \alpha$-reductase activity. After an initial decrease, esterase activity increased gradually from Day 25, although a complete restoration was not obtained before Day 76 after EDS administration.

A comparison of testicular $5 a$-reductase activity in testes from normal 30-day-old rats and from adult rats showed that the $5 \alpha$-reductase activity (expressed as the sum of nmol $5 \alpha$ dihydrotestosterone, $5 \alpha$-androstane- $3 \alpha, 17 \beta$-diol and $5 \alpha$-androstane- $3 \beta, 17 \beta$-diol formed per min per $\mathrm{g}$ testicular tissue) was 30 -fold lower in adult rats $(0.65 \pm 0.26 \mathrm{nmol} / \mathrm{min} / \mathrm{g}$, mean \pm s.e.m. $)$ than in 30 -day-old rats $(19.3 \pm 1 \cdot 1 \mathrm{nmol} / \mathrm{min} / \mathrm{g})$. At 30 days after treatment of mature rats with EDS the $5 \alpha$-reductase activity $(3.80 \pm 1.7 \mathrm{nmol} / \mathrm{min} / \mathrm{g})$ was 6 -fold increased when compared to untreated controls but 5 times lower than in immature animals.

In testes of adult EDS-treated rats many newly formed Leydig cells contained large lipid droplets in their cytoplasm 30 days after EDS administration (Fig. 2). Leydig cells from 30-day-old (pubertal) rats also contained many lipid droplets in the cytoplasm (Fig. 3), but the nuclei of these cells appeared to be smaller than in the newly formed Leydig cells 30 days after EDS administration.

\section{Discussion}

The results of the present study confirm that, after administration of EDS to adult male rats, the Leydig cells are eliminated and that serum concentrations of androgens are low for more than 14 days. Due to the appearance of new Leydig cells, a gradual restoration of serum androgens occurs (Morris \& McCluckie, 1979; Bartlett et al., 1986; Molenaar et al., 1986b). The temporal changes in serum $3 \alpha$-androstanediol concentrations, however, were markedly different from those of testosterone. The concentration of $3 \alpha$-androstanediol showed a transient rise with the highest level on Day 35. The alterations in the serum level of $3 \alpha$-androstanediol closely followed the changes in testicular $5 \alpha$-reductase activity and confirm that the activity of the $5 \alpha$-reductase is of major importance for the secretion of $3 \alpha$-androstanediol (Purvis et al., 1980).

The elevated serum concentration of $3 \alpha$-androstanediol and the high $5 \alpha$-reductase activity during the regeneration of Leydig cells after EDS are reminiscent of the high levels of plasma $3 \alpha$-androstanediol and $5 \alpha$-reductase found in pubertal male rats around Week 5 of life (van der Molen et al., 1975; Rosness et al., 1977; Corpéchot et al., 1981). Since it is well established that the activity of the $5 \alpha$-reductase and $3 \alpha$-oxidoreductase is much higher in interstitial cells than in seminiferous tubules (van der Molen et al., 1975; Yoshizaki et al., 1978), most of the testicular $5 \alpha$-reduced metabolites are produced and secreted by the interstitial cells. Nevertheless, the regenerating seminiferous tubules might also have contributed to the rise in testicular $5 \alpha$ reductase and serum $3 \alpha$-androstanediol (Welsh $\&$ Wiebe, 1978). In pubertal rats the serum $3 \alpha$-androstanediol concentration is about 2 -fold higher than that of testosterone, whereas in the serum of mature rats treated with EDS $3 \alpha$-androstanediol values were lower than testosterone concentrations. This difference in androstanediol:testosterone ratio between immature rats and EDS-treated rats is probably caused by the fact that the $5 \boldsymbol{\alpha}$-reductase activity in the testes of pubertal rats is appreciably higher than in EDS-treated rats. The relatively low specific activity of $5 \alpha$-reductase in the testes of EDS-treated rats can be explained by the lower Leydig cell numbers in EDS-treated rats. Data presented by Bartlett et al. (1986) and Kerr et al. (1987) indicate that the number of Leydig cells per gram of testis is smaller in EDS-treated rats than in their adult controls. This finding and the observation that the Leydig cell concentration in the testes of pubertal rats is higher than in adult rats (Zirkin \& Ewing, 1987) led to the conclusion that the testes of EDS-treated rats have an appreciably lower Leydig cell concentration than do the testes of pubertal animals. An additional explanation for the relatively low specific $5 \alpha$-reductase in the testes of EDS-treated rats 


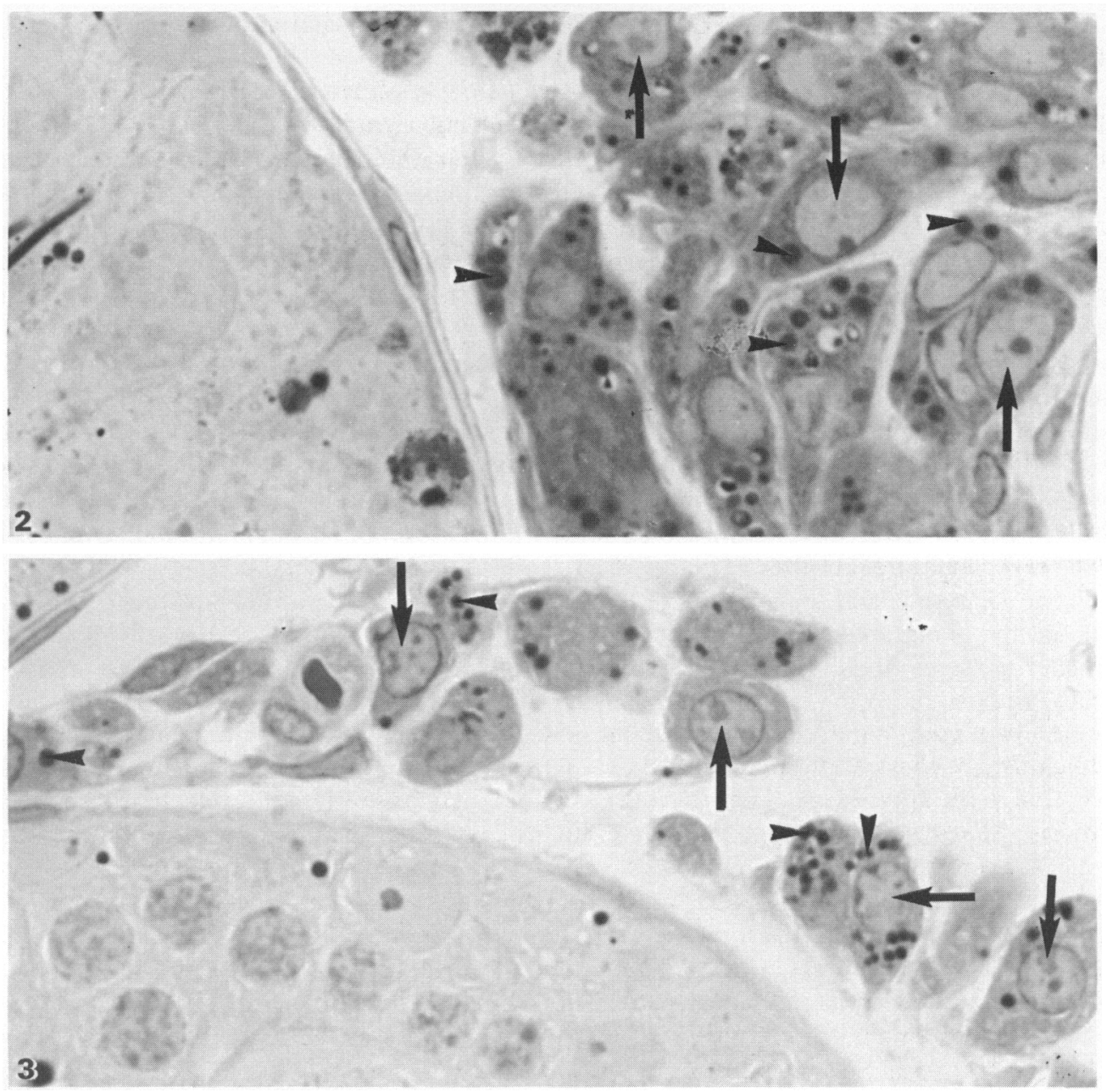

Fig. 2. Testis of an adult rat 30 days after EDS administration. Many newly developed Leydig cells (arrows) are present which often contain a large nucleus and numerous lipid droplets (arrow heads) in the cytoplasm. $\times 590$.

Fig. 3. Leydig cells (arrows) present in the interstitial tissue of a pubertal (30-day-old) rat. Numerous lipid droplets (arrow heads) are present in the cytoplasm. $\times 590$.

might be the high gonadotrophin concentrations during the regeneration of the Leydig cells (Jackson \& Morris, 1977; Bartlett et al., 1986; Molenaar et al., 1986b), since administration of gonadotrophins to immature rats causes a strong reduction in the testicular $5 \alpha$-reductase (Ficher \& Steinberger, 1979). Finally, it may also be possible that after treatment with EDS only a part of the total Leydig cell population develops according to a pubertal developmental pattern, in which $5 \alpha$-reductase activity is transiently expressed.

Parallel changes in esterase activity after EDS treatment and during normal pubertal development were found. During pubertal development the esterase activity is low during the first 26 days of age. Then, a marked increase in enzyme activity occurs until adult values are reached around Day 70 (Meyer et al., 1974). In the present experiment, the gradual rise in esterase activity takes 
place between Days 25 and 76 after EDS and shows that the complete development from precursor cells into 'mature' Leydig cells takes more than 25 days.

The temporal changes in steroid concentrations and enzyme activities after EDS, and the fact that fetal and neonatal rat testes have a very low $5 \alpha$-reductase activity (Ficher $\&$ Steinberger, 1971; Rivarola et al., 1975; Purvis et al., 1980), indicate that the Leydig cells which repopulate the testicular interstitium after EDS treatment resemble more the pubertal than the fetal-neonatal cell. This conclusion is at variance with morphological studies from which it is suggested that the Leydig cells which develop after EDS mainly follow a fetal-like developmental pattern. In the present study the occurrence of numerous lipid droplets in the Leydig cells of EDS-treated rats was confirmed (Kerr et al., 1985; Bartlett et al., 1986; Jackson, N. C. et al., 1986), but a large number of lipid droplets was also present in the cytoplasm of most pubertal Leydig cells. Similar observations in pubertal rats were made by Zirkin \& Ewing (1987). Lipid droplets are therefore an easy but not a suitable marker to discriminate between fetal and pubertal Leydig cells. However, the size of the nuclei of the Leydig cells formed after EDS administration appeared larger than those of pubertal Leydig cells. Since large nuclei and mitochondria with tubular cristae occur in fetal Leydig cells and in Leydig cells after EDS administration (Kerr et al., 1985; Jackson, N. C. et al., 1986), some of the Leydig cells in mature rats after EDS treatment can be designated as fetal cells.

From our results and the data in the literature, we conclude that, after treatment with EDS, fetal-like and pubertal-like characteristics can be found in the developing Leydig cells. When both characteristics are present in one single cell type simultaneously, this could indicate that after EDS the development of Leydig cells occurs via an abnormal pathway. Alternatively, if the two characteristics are present in different cell types this may indicate that different developmental processes occur. Further investigations are required to determine which of these possibilities is correct.

We thank P. Landsmeer for secretarial assistance.

\section{References}

Bartlett, J.M.S., Kerr, J.B. \& Sharpe, R.M. (1986) The effect of selective destruction and regeneration of rat Leydig cells on the intratesticular distribution of testosterone and morphology of the seminiferous epithelium. $J$. Androl. 7, 240-253.

Bu'Lock, D.E. \& Jackson, C.M. (1975) Suppression of testicular androgen synthesis in the rat by ethane 1,2, dimethanesulphonate. J. Steroid Biochem. 6, 1181-1185.

Corpéchot, C., Baulieu, E.E. \& Robel P. (1981) Testosterone, dihydrotestosterone and androstanediols in plasma, testes and prostates of rats during development. Acta endocr., Copenh. 96, 127-135.

Ficher, M. \& Steinberger, E. (1971) In vitro progesterone metabolism by rat testicular tissue at different stages of development. Acta endocr., Copenh. 68, 285-292.

Ficher, M. \& Steinberger, E. (1979) Effects of HCG and PMS on bioconversion of progesterone, androstenedione and testosterone in immature rat testes. $J$. Steroid Biochem. 10, 601-607.

Jackson, A.E., O'Leary, P.C., Ayers, M.M. \& de Kretser, D.M. (1986) The effects of ethylene dimethane sulphonate (EDS) on rat. Leydig cells: evidence to support a connectipe tissue origin of Leydig cells. Biol. Reprod. 35, 425-437.

Jackson, C.M. \& Morris, I.D. (1977) Gonadotrophin levels in male rats following impairment of Leydig cell function by ethylene dimethanesulphonate. Andrologia 9, 29-35.
Jackson, N.C., Jackson, H., Shanks, J.H., Dixon, J.S. \& Lendon, R.G. (1986) Study using in-vivo binding of ${ }^{125}$ I-labelled hCG, light and electron microscopy of the repopulation of rat Leydig cells after destruction due to administration of ethylene-1,2-dimethanesulphonate. J. Reprod. Fert. 76, 1-10.

Kerr, J.B., Donachie, K. \& Rommerts, F.F.G. (1985) Selective destruction and regeneration of rat Leydig cells in vivo. A new method for the study of seminiferous tubular-interstitial interaction. Cell Tissue Res. 242, 145-156.

Kerr, J.B., Bartlett, J.M.S., Donachie, K. \& Sharpe, R.M. (1987) Origin of regenerating Leydig cells in the testis of the adult rat. An ultrastructural, morphometric and hormonal assay study. Cell Tissue Res. 249, 367-377.

Meijs-Roelofs, H.M.A., Kramer, P., van Cappellen, W.A. \& Woutersen, P.J.A. (1985) Changes in serum concentration and ovarian content of $5 \alpha$-androstane$3 \alpha, 17 \beta$-diol in the female rat approaching first ovulation. Biol. Reprod. 32, 301-308.

Meyer, E.H.H., Forsgren, K., Von Deimling, O. \& Engel, W. (1974) Induction of nonspecific carboxyl esterase in the immature rat testis by human chorionic gonadotropin. Endocrinology 95, 1737-1739.

Moger, W.H. (1977) Serum $5 \alpha$-androstane-3 $\alpha, 17 \beta$-diol, androsterone, and testosterone concentrations in the male rat. Influence of age and gonadotropin stimulation. Endocrinology 100, 1027-1032. 
Molenaar, R., Rommerts, F.F.G. \& van der Molen, H.J. (1986a) Non-specific esterase: a specific and useful marker enzyme for Leydig cells from mature rats. $J$. Endocr. 108, 329-334.

Molenaar, R., de Rooij, D.G., Rommerts, F.G.G. \& van der Molen, H.J. (1986b) Repopulation of Leydig cells in mature rats after selective destruction of the existent Leydig cells with ethylene dimethane sulfonate is dependent on luteinizing hormone and not folliclestimulating hormone. Endocrinology 118, 2546-2554.

Morris, I.D. \& McCluckie, J.A. (1979) Temporal changes in serum androgen after temporary impairment of Leydig cell function by ethane-1,2,dimethane sulphonate. J. Steroid Biochem. 10, 467-469.

Morris, I.D., Philips, D.M. \& Bardin, W.C. (1986) Ethylene dimethanesulfonate destroys Leydig cells in the rat testis. Endocrinology 118, $709-719$.

Purvis, K., Clausen, O.P.F. \& Hansson, V. (1980) Effects of age and hypophysectomy on responsiveness of rat Leydig cells to HCG. J. Reprod. Fert. 60, 77-86.

Rao, P.N., Khan, A.H. \& Moore, P.H., Jr (1977) Synthesis of new steroid haptens for radioimmunoassay. Part III. 15 $\beta$-carboxyethylmercapto steroid-bovine serum albumin conjugates. Specific antisera for radioimmunoassay of $5 \alpha$-dihydrotestosterone, $5 \alpha$-androstane$3 \beta, 17 \beta$-diol and $5 \alpha$-androstane-3 $\alpha, 17 \beta$-diol. Steroids 29, 171-184.

Rivarola, M.A., Podesta, E.J., Chemes, H.E. \& Calandra, R.S. (1975) Androgen metabolism and concentration in the seminiferous tubulus at different stages of development. J. Steroid Biochem. 6, 365-369.

Rommerts, F.F.G., van Doorn, L.G., Galjaard, H., Cooke, B.A. \& van der Molen, H.J. (1973) Dissection of wet tissue and of freeze-dried sections in the investigation of seminiferous tubules and interstitial tissue from rat testis. J. Histochem. Cytochem. 21, 572-579.
Rosness, P.A., Sunde, A. \& Eik-Nes, K.B. (1977) Production and effects of $7 \alpha$-hydroxytestosterone on testosterone and dihydrotestosterone metabolism in rat testis. Biochim. Biophys. Acta 488, 55-68.

Teerds, K.J., de Rooij, D.G., Molenaar, R., Rommerts, F.F.G. \& Wensing, C.J.G. (1986) Specific cytoxic effects of ethane dimethyl sulfonate (EDS) and repopulation of Leydig cells after depletion. In Molecular and Cellular Endocrinology of the Testis, pp. 173-183. Eds M. Stefanini, M. Conti, R. Geremia \& E. Ziparo. Elsevier Science Publishers B.V., Amsterdam.

van der Molen, H.J., Grootegoed, J.A., de Greef-Bijleveld, M.J., Rommerts, F.F.G. \& van der Vusse, G.J. (1975) Distribution of steroids, steroid production and steroid metabolizing enzymes in rat testis. In Hormonal Regulation of Spermatogenesis, pp. 3-23. Eds F. S. French, V. Hansson, E. M. Ritzen \& S. N. Nayfeh. Plenum Publishing Corporation, New York.

Verjans, H.L., Cooke, B.A., de Jong, F.H., de Jong, C.M.M. \& van der Molen, H.J. (1973) Evaluation of a radioimmunoassay for testosterone estimation. $J$. Steroid Biochem. 4, 665-676.

Welsh, M.J. \& Wiebe, J.P. (1978). Sertoli cell capacity to metabolize $\mathrm{C}_{19}$ steroids: Variation with age and the effect of follicle-stimulating hormone. Endocrinology 103, 838-844.

Yoshizaki, K., Matsumoto, K. \& Samuels, L.T. (1978) Localization of $\Delta^{4}$-5 $\alpha$-reductase in immature rat testes. Endocrinology 102, 918-925.

Zirkin, B.R. \& Ewing, L.L. (1987). Leydig cell differentiation during maturation of the rat testis: a stereological study of cell number and ultrastructure. Anat. Rec. 219, 157-163.

Received 4 November 1987 